\title{
Analysis of the Integrated Farming Income in the SMD (Sarjana Membangun Desa) Program in Padang City (Case Study: Tani Ternak Sepakat Group)
}

\author{
Amelira Haris Nasution, ${ }^{1}$, Nofialdi ${ }^{2}$, and Ferdhinal Asful ${ }^{2}$ \\ ${ }^{1}$ Horticultural Agribusiness Department, Politeknik Wilmar Bisnis, Indonesia \\ ${ }^{2}$ Agribusiness Department, Agricultural Faculty, Andalas University, Indonesia
}

\begin{abstract}
The purpose of this research is to analyze pre and post farmers' income who develop the integrated farming system in the SMD Program in Padang City. Tani Ternak Sepakat Group is used as a case study. This research was conducted in Kurao Pagang, Padang City, West Sumatera. In this research, descriptive qualitative and descriptive quantitative designs were used. The results of this study showed that Tani Ternak Sepakat Groups has implemented the integration of paddy farming and breeding in their farming system, funded by SMD Program. For breeding activity, The Tani Ternak Sepakat group raises both goats and cows. At the same time, the farmer group also cultivates paddy only for integrating between paddy farming and cattle. The integration is done through the use of cattle's compost as paddy farming fertilizer and the use of paddy's farming residues for feeding the cattle. However, these practices reduce farmers' income by $95.12 \%$ for the first years of the program. Based on the study, it is suggested that farmers should implement waste treatment technology that utilizes available resources and to increase their income.
\end{abstract}

Keywords: integrated farming system, farmers' income, SMD program

Received 25 February 2019 | Revised 03 April 2019 | Accepted 09 May 2019

\section{Introduction}

Suistainable agriculture is always a topical issue to address in environmentally friendly agriculture development. Sustainable agriculture system can be implemented using several technological developments or modeling system, one of which is an integrated farming system [1]. The Integrated farming system is able to maintain the ecosystem balance to equalize between the flow of nutrients and energy [2]. Integrated farming system contains three important aspects namely efficiency, independence and sustainability of ecology, economy and socio-culture [3].

\footnotetext{
*Corresponding author at: Politeknik Wilmar Bisnis Indonesia, Jl. Kapten Batu Sihombing, Medan Estate, Percut Sei Tuan, Kabupaten Deli Serdang, Sumatera Utara, 20371, Indonesia

E-mail address: amelira.nasution@wbi.ac.id
} 
However, in reality, the implementation of integrated farming system concept is never as smooth as its designed concept, due to limited resources such as land as well as livestock ownership, which is one of the important components in the integrated farming system. To solve the livestock problems, the government provides social empowerment program through Program Sarjana Membangun Desa/Village Development by The Scholars (SMD Program)

The SMD program empowers breeder farmer groups through the transfer of technology from universities to the community, where the entrepreneurial spirit of the community will be enhanced. The SMD program that has been implemented since 2007 focuses on the development of breeder business and receives goverment support to realize the 2014 Beef Self-Sufficiency Program [4]. The SMD program was expected to increase the agricultural economy from the cultivation sector.

In integrated farming system, it is necessary to recycle waste from farm. Breeder activities will produce organic waste (compost), which can be used as an input for paddy farming. On the other hand, the residue of paddy farming activities is used to feed the cattle (input). In this system, the SMD program is expected to provide multiple effects which eventually is expected to improve the farmers' income.

Economic aspects in integrated farming system are related to increasing efficiency. This efficiency improvement has an impact on an increase of farmers' income. It is possible to compare the farmer's income, before and after the implementation of integrated farming system in the SMD Program. Hence, this research provides its significance as a way to compare and analyze farmer's income before and after the application of integrated farming system development with SMD Program in Padang City (Case Study: Tani Ternak Sepakat Groups).

\section{Literature Review}

The integrated farming system concept has long been known and applied by the farmers since the introduction of agriculture . However, in practice, most farmers do not realize the advantages and disadvantages of integrated farming system towards environmental sustainability. Integrated Farming System (SITANDU) is an agricultural system that integrates the agricultural sub-sector (plants, livestock, fish) to improve the efficiency and productivity of land resources, independence, farmers' welfare in a sustainable manner [3]. Integrated farming system promotes recycling concept between plantations, fisheries and livestock [5]. Integrated farming system can be seen as part of agro-ecotechnology that linked various components such as off-farm, natural bio-physical and socio-economic-political-cultural simultenously. All components in agroecotechnology have an impact on decision-making process as well as the selected technology options for farmers to determine the kind of combination to earn higher profits than others do. 
When farmers use an integrated farming system, they will increase their income [6]. Thats why, it is possible to analyze farmer's use of integrated farming system through farm business analysis. Farming is a study to allocate the resources effectively and efficiently for gaining high profits at a certain time. To achieve effectiveness, farmers shall allocate their resources they have (which are controlled) wisely; while to achieve efficiency, farmers are entitled to utilize these resources to produce the output that exceeded the input [7].

In terms of Economy, the concept of integrated farming system is explained by the concept of multiple production [8]. This concept is related to the entrepreneur's decision to produce two or more products that will maximize farming income using minimal resource. This concept is shown by the production possibility curve (KKP) which is an opportunity curve to indicate an increase in the amount of production of a certain product followed by a reduction in the production of other products [9].

Farm efficiency can be measured by calculating technical efficiency, price efficiency and economic efficiency [7]. When conducting farming analysis, researcher can adjust the analysis by interest. Many farming researches analyses are conducted by farmers or producers as a way of knowing or investigating about 1) comparative adventage, 2) law of diminishing returns, 3) substitution effect), 4) farm expenditure, 5) opportunity cost, 6) ownership of various plants, and 7) goal trade-off [7].

Based on the analysis, integrated farming system development can increase the income received by farmers. The implementation of integrated farming system is better than non-integrated farming system since the farmers can receive higher income [6]. On the other hand, the application of the integrated farming model is also very important in increasing the total output of the region in the form of an increase in the number of livestock due to the use of waste to become a zero waste [8].

\section{Research Method}

The study was conducted at the Tani Ternak Sepakat Group in Padang City. This study was conducted from June 2012 to July 2012. This study used a descriptive method with a case study approach. Within the group there are 8 members so that all of them are respondents for this study. The data were collected using primary data and secondary data. Afterwards, the data were analyzed using qualitative and quantitative analysis to get the picture of farmers' income.

The calculated income is the received income by farmers before and after obtaining financial assistance from the SMD Program in developing the integrated farming system. Farming income is the multiplication of production obtained by selling prices [7]. The equation can be written as follows: 
Where:

$$
\mathrm{T} R=X_{i} \cdot H_{x}
$$
a. Paddy's Farming business
b. Livestock Business
$\mathrm{TR}=$ Total Revenue $(\mathrm{Rp} / \mathrm{Year})$
$\mathrm{TR}=$ Total Revenue $(\mathrm{Rp} / \mathrm{Year})$
$\mathrm{Xi}=$ Amount of production $(\mathrm{Kg} / \mathrm{Year})$
$\mathrm{Xi}=$ Number of cattle sold (Number/ Year)
$\mathrm{Hx}=$ Selling price at the farmer
$\mathrm{Hx}=$ Selling price of livestock $(\mathrm{Rp} /$ Number $)$

Farmer's income can be calculated using the following formula:

Where:

$$
Y_{i}=\left(X_{i} \cdot H_{x}\right)-B_{t}
$$

$$
\begin{array}{ll}
\text { a. Paddy's Farming business } & \text { b. Livestock Business } \\
\mathrm{Yi}=\text { Income }(\mathrm{Rp} / \mathrm{Ha} / \mathrm{Year}) & \mathrm{Yi}=\text { Income (IDR/Ha/Year) } \\
\mathrm{Xi}=\text { amount of production }(\mathrm{Kg} / \mathrm{Ha}) & \mathrm{Xi}=\text { Number of cattle sold (Number/ Year) } \\
\mathrm{Hx}=\text { Grain selling price }(\mathrm{Rp}) & \mathrm{Hx}=\text { Selling price of livestock (Rp/ Number) } \\
\mathrm{Bt}=\text { Real Cost }(\mathrm{Rp} / \mathrm{Ha} / \mathrm{Year}) &
\end{array}
$$

\section{Results and Discussion}

\subsection{Implementation of Integrated Farming System Development}

The development of integrated farming system in the SMD Program conducted by The Tani Ternak Sepakat Groups is done by integrating between two components, paddy's farming and breeding. Paddy is cultivated in two planting seasons in a year. The breeding business funded by the SMD Program has two periods and two types of breeding, the first period of which is goat and the second period of which is cattle.

Integrated farming system is a zero waste system by utilizing the output of one component as the input for other components. However, in goat farming, there was no integration between goat farming and paddy's farming, because the output of goat farming was not used as the input for paddy's farming, and conversely the output of paddy's farming was not used as the input for goat farming. Therefore, the concept of integrated farming system is not apparent in paddys farming with goat farming.

Unlike the goat farming, the integrated farming system is applicable for the cattle farming. The paddy's farming output (straw as residues) can be used as the input (feeding) for cattle. The output from the cattle farm (cow dung/ residues) can be used as input (fertilizer) for paddy's farming. In this activity, there are two simple integrations in techno-ecology, which consist of two patterns, (1) integration between cattle breeding and paddy'sfarming (C-P) and the reverse integration of (2) integration between paddy's farming and cattle breeding (P-C). 
The integration between cattle breeder and paddy's farming lies in the utilization of output from cattle farms in the form of waste (cow manure) as the input (fertilizer) for paddy's farming. Cow manure is used as a fertilizer for paddy's plants. However, the utilization of cow manure for paddy's farming in cattle farming groups was carried out without waste management activities. The farmers used piling up cow manure $t$ for one month without adding any decomposers such as Effective Mocro-Organism (EM) and Local Microorganisms (MOL) as activators in decomposition of cow manure. In this way, the effectiveness in the decomposition process is not obtained because of lengthy process.

In addition to producing grain, paddy's farming activities also produce waste (straw) as the output. The straw can be used as feed ingredients (inputs) for cattle farm, which indicate the second pattern. of the integration between paddy's and cattle. In this research, the Tani Ternak Sepakat Groups feed the fresh straw to cattle without any process. They feed the cattle with the straw when one of the group members conducted rice harvesting. On the harvest day, usually the straw is collected for a stock for three days to one week. However, in case no group members conducting any harvest, the feeds source is taken from the existing crop waste. Straw feeding is provided when forage feed cannot satisfy the need of the cattle.

The Straw Ammonia activity is a technology to be used by farmer groups. Unfortunately, this farmer group has never used this technology because they think that the activity is time consuming. Feeding the cows with fresh food is actually not an effective way to increase the cattle weight, because the fiber content of each paddy stem cannot be completely destroyed by the cattle rumen. Thus, the nutrients needed by cattle are not fully met. Before beinge used as cattle feed, the straw is fermented for two weeks to one month. The ammoniation process is conducted using urea or molasses to break the hard parts on the paddy segments. Ammonia straw can make it easier for farmers to provide cattle feed without dependence on forage feed.

The benefits of integrated farming system development can be seen through the integration system created. Two patterns of integration systems provide environmentally friendly agricultural products. The two patterns are the integration between cattle and paddy and the integration between rice and cattle. In addition, integrated farming system also reduces the cost of agricultural and livestock production facilities.

\subsection{Comparison of Farmer Income Analysis}

The analysis draws the conclusion on paddy's farming income and livestock farm income. The comparisons were made to examine differences of income levels of farmers before and after getting the SMD Program. The comparison was based on the level of income before and after obtaining the SMD Program of paddy's farming in 2010 and 2011, whichconsists of two planting seasons in each year, March-June and November-February. The basis for calculating livestocks 
in 2011 is from February to April for the maintenance of goats farm and from May to November for raising cattle farm.

\subsubsection{Paddy's farm business}

The average land area of the sample farmers is 0.37 ha. Paddy's cultivation is carried out in two planting seasons in one year. Planting season 1 was done in March until June and planting season 2 was done in November until February. Farming costs that are calculated are all costs incurred or paid by sample farmers in financing their farming needs. In this study, the calculated cost is the overall cost of rice farming activities, namely the cost of seeds, labor, maintenance to postharvest. The labor costs are calculated in the Male Working Day (HKP) unit.

Base on this research, the increasing net income after getting the SMD program was of $7.51 \%$. The amount of income received by sample farmers can be seen in Table 1 .

Table 1. Analysis of Paddy's Farming Income per Planting Season

\begin{tabular}{lrrrr}
\hline \multirow{2}{*}{ Description } & \multicolumn{2}{c}{ Before SMD Program } & \multicolumn{2}{c}{ After SMD Program } \\
\cline { 2 - 5 } & $\begin{array}{c}\text { IDR/Farmer/PS } \\
\mathbf{1}\end{array}$ & $\begin{array}{c}\text { IDR / Farmer/PS } \\
\mathbf{2}\end{array}$ & $\begin{array}{c}\text { IDR/Farmer/PS } \\
\mathbf{1}\end{array}$ & $\begin{array}{c}\text { IDR/Farmer/PS } \\
\mathbf{2}\end{array}$ \\
\hline Revenue & $5,194,000$ & $4,953,333,33$ & & \\
Cost & & & & \\
$\quad$ Seed & $95,431.11$ & $94,771.11$ & $101,333.33$ & $100,541.67$ \\
Fertilizer & 588,400 & 588,400 & 368,400 & 268,400 \\
Pesticide & 20,000 & 26,667 & 20,000 & 26,667 \\
$\quad$ Labor & 373,333 & 371,667 & 373,333 & 371,667 \\
Total Cost & $1,076,831.11$ & $1,081,171.11$ & $863,066.67$ & 767,275 \\
Income & $4,117,168.89$ & $3,872,162.22$ & $4,374,933.33$ & $4,192,725$ \\
Net income* & $\mathbf{2 , 8 7 4 , 7 9 5 . 5 6}$ & $\mathbf{2 , 7 3 0 , 1 9 7 . 7 8}$ & $\mathbf{3 , 0 6 0 , 2 2 2 . 2 2}$ & $\mathbf{2 , 9 6 6 , 0 4 7 . 2 2}$ \\
\hline
\end{tabular}

*used profit sharing system

The sample of farmer's gross income received in one year (twice planting season) before getting the SMD Program was IDR 7,989,331.11,- and after getting the SMD Program it was IDR $8,567,658.33$. However, the sample farmers could not enjoy the increasing income because they had a profit sharing system with the owners of paddy fields. This situation according to Soekartawi (1986) is a characteristic of smallholder farmers in Indonesia, in addition to small capital ownership and a simple management system.

\subsubsection{Goat farm funded by the SMD program}

The calculated goat farm cost is all cash costs paid by farmers in financing the farm needs and funded by the SMD Program. In this research, the calculated cost is all cost in this goat farm, like lamb, cultivation, and sale. Farming activity was started from February 2011 until April 2011. In this season, farmers did not get any income due to the harvest failure. 
Table 2. Analysis of Goat Farming Income

\begin{tabular}{lrr}
\hline \multicolumn{1}{c}{ Description } & Total (IDR/Period) & Total (IDR/Period) \\
\hline Revenue & & $4,800,000$ \\
Cost & & \\
$\quad$ Lamb & $53,100,000$ & \\
$\quad$ Land Rent & 350,000 & \\
$\quad$ Electricity cost & 120,000 & \\
Total Cost & & $53,570,000$ \\
Income (Lost) & & $(48,770,000)$ \\
Profit Sharing for SMD (20\%) & $\mathbf{( 9 , 7 5 4 , 0 0 0 )}$ \\
Balance & & $(39,016,000)$ \\
Profit Sharing for groups member & $\mathbf{( 3 , 5 4 6 , 9 0 9 . 6 7 )}$ \\
\hline
\end{tabular}

Losses experienced in goat cultivation of SMD have made the farmers as members of livestock farmer groups failed to receive (Remaining Operating Results). However, in this study, these losses are still calculated in total.

\subsubsection{Cattle farming funded by the SMD program}

The livestock cost in cattle farming is all costs paid by livestock farmer groups in financing their livestock business needs. Cost paid in this study relates to overall cost, like calves, cultivation, and sale. This livestock business activity was only counted for one time period, from May 2011 until November 2011. Based on the research, the profit sharing system was implemented and SMD earned revenues of $20 \%$ of the total revenue. This means that SMD received IDR 1,081,366.67, - and each farmer would receive IDR 393,224.24.

Table 3. Analysis of Cattle Farming Income

\begin{tabular}{lrr}
\hline \multicolumn{1}{c}{ Description } & Total (IDR/Period) & Total (IDR/Period) \\
\hline Revenue from cattle farming & $35,130,000$ & \\
Revenue by-products & 735,000 & \\
Total Revenue & & $35,865,000$ \\
Cost & & \\
$\quad$ Calves & $27,500,000$ & \\
$\quad$ Fedd cost & $1,396,500$ & \\
$\quad$ Drug Cost & 465,000 & \\
$\quad$ Renting land Cost & $816,666.67$ & \\
$\quad$ Electricity cost & 280,000 & $30,458,166.67$ \\
Total Cost & & $\mathbf{5 , 4 0 6 , 8 3 3 . 3 3}$ \\
Income (Lost) & & $\mathbf{1 , 0 8 1 , 3 6 6 . 6 7}$ \\
Profit Sharing for SMD (20\%) & & $4,325,466.66$ \\
Balance & & $\mathbf{3 9 3 , 2 2 4 . 2 4}$ \\
Profit Sharing for groups member & & \\
\hline
\end{tabular}

The real received income by SMD was IDR 1,100,000 and the income for each member was IDR 400,000. The calculation of income made by researchers was greater because it included 
additional income from the sale of cow manure as part of the total revenue and considered the purchase price of additional feed for regular needs.

\subsubsection{Analysis of total farmer income}

In this analysis, the total income of farmers before and after getting the SMD Program was compared by the profit sharing system. Farming income in this analysis is derived from paddy's farm income in 1 year (2 planting seasons) and goat farming and cattle business (SMD Program). Although goat livestock businesses suffer losses, they are still considered to have a contribution to the total income of farmers in one year.

From Table 4, it is known that there was a decrease in farmer's income after getting a SMD Program of $95.12 \%$. The decrease was caused by losses in goat farming, which affected the total income of farmers. In addition, the lack of capital to purchase cattle also negates side income.

Thus, it is apparent that the SMD program could not increase farmers' net income. Apart, from these disadvantages, the good thing about this program is that integrated farming activities provide benefits, like assets, which can be used by the livestock farmer groups. In addition, this livestock farmer group is also continuing for the second period of cattle business. In 2013, the cattle business had experienced a development from the increasing number of cattle raised.

Table 4. Comparison of Farmer Income

\begin{tabular}{clcc}
\hline No & \multicolumn{1}{c}{ Description } & $\begin{array}{c}\text { Before SMD } \\
\text { Program }\end{array}$ & \multicolumn{1}{c}{$\begin{array}{c}\text { After SMD } \\
\text { Program }\end{array}$} \\
\hline A & $\begin{array}{l}\text { Farmers Net income from Paddy's farming } \\
\text { (IDR/Year) }\end{array}$ & $5,604,993$ & $6,026,269$ \\
B & $\begin{array}{l}\text { Farmers Net income from SMD Program } \\
\text { (IDR/Year) }\end{array}$ & - & \\
& $\begin{array}{l}\text { 1. Goat Farming (Goat Livestock) } \\
\text { (IDR/Period) }\end{array}$ & & $(3,546,909.09)$ \\
& $\begin{array}{l}\text { 2. Cattle Farming (Cattle Livestock) } \\
\text { (IDR/Period) }\end{array}$ & & $393,224.24$ \\
C & Total Income (IDR/Years) & $\mathbf{5 , 6 0 4 , 9 9 3}$ & $\mathbf{2 , 8 7 2 , 5 8 4 . 1 5}$ \\
\hline
\end{tabular}

\section{Conclusions and Recomendation}

\subsection{Conclusions}

Integreted farming system development using SMD Program has integrated between paddy's farming and cattle farming. Integrated farming system development that was done by Tani ternak Sepakat Groups was performed using paddy's waste (strew) for input (cattle feed) and used catle waste (cattle manure) for input (paddy's farming fertilizer).

In the first year of the implementation of the SMD Program, these livestock farmer groups suffered losses, which decreased the total income of farmers in the integrated agricultural development activities by $95.12 \%$, by taking into account the costs paid, production and selling prices. This evidence is seen by the total net income received by farmers which became lower 
after receiving the program than that before the SMD Program, from IDR 5,604,993 to IDR $2,872,584.15$

\subsection{Suggestion}

By analyzing the data about Integrated Farming Income in the SMD Program in Padang City (Case Study: Tani Ternak Sepakat Group), the researcher suggested that farmers increase their farmer income by utilizing integrated farming. Meanwhile, for the sake of environmental development, it is recommended that waste treatment technology that utilizes available resources (cow manure and straw fermented using MOL and EM) should be applied to ensure the success of integrated agricultural activities.

\section{REFERENCES}

[1] B. Praptono, "Kajian pola bertani padi sawah di Kabupaten Pati ditinjau dari sistem pertanian berkelanjutan (Studi kasus di Kecamatan Pati)", Master Thesis, Program Pasca Sarjana Unversitas Diponegoro, 2010.

[2] S. W. Atmojo, "Pertanian organik, integrasi ternak dan tanaman," Undergraduated Thesis, Fakultas Pertanian, Universitas Negeri Semarang, Solo, 2007.

[3] Purwono, "Implementasi pertanian terpadu dalam rangka meningkatkan efisiensi sumber daya lahan," Kuliah Pembekalan Kuliah Kerja Profesi, Fakultas Pertanian, Institut Pertanian Bogor, Bogor, 2009.

[4] Direktorat Jenderal Peternakan Kesehatan Hewan. Pedoman Pelaksanaan Pengajuan Pengelolaan Dana Bantuan Sosial Tahun Anggaran 2012. 2012.

[5] D. Prajitno, "Sistem usaha tani terpadu sebagai model pembangunan pertanian berkelanjutan di tingkat petani," Pidato Pengukuhan Jabatan Guru Besar Fakultas Pertanian, Universitas Gadjah Mada, Yogyakarta, 2009.

[6] H. S. Artise, A. H. S. Salendu, S. Maryunani, and B. Polii, "Integration of cattle-coconut farming in South Minahasa Regency," Proceeding of the 2nd International Seminar on Animal Industry Jakarta, 5-6 July 2012.

[7] Soekartawi, Analisis Usaha Tani, UI-PRESS. Jakarta, 1995.

[8] F. Maudi and N. Kusnadi, "Model usahatani terpadu sayuran organik-hewan ternak (Studi kasus: Gapoktan Pandan Wangi, Desa Karehkel, Kecamatan Leuwiliang, Kabupaten Bogor, Provinsi Jawa Barat)," Forum Agribisnis, vol. 1, no. 1, 2011.

[9] A. T. Cesari, "Analisis Usahatani Terpadu Pada Anugrah Farm Di Kecamatan Tajur Halang Kabupaten Bogor," Undergraduate Thesis, Program Studi Agribisnis, Fakultas Ekonomi dan Manajemen, Institut Pertanian Bogor, 2014. 